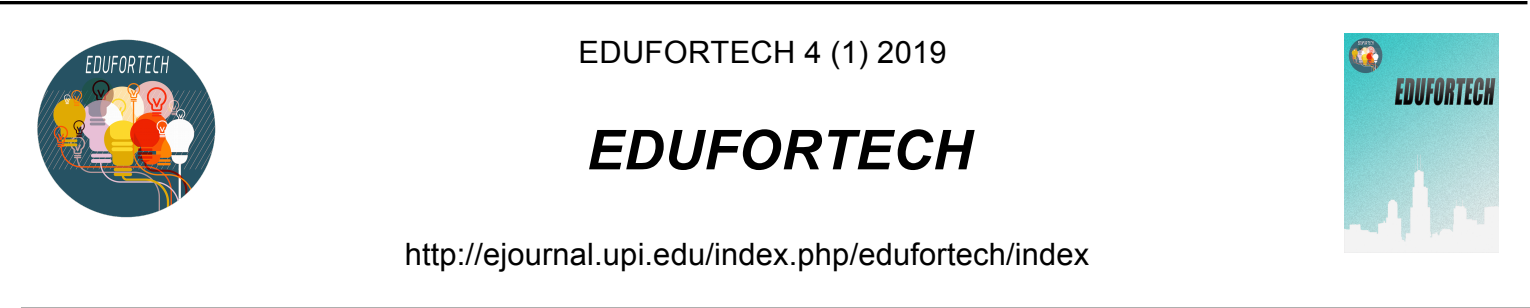

\title{
STUDI PEMANFAATAN TEPUNG BUAH PISANG DAN KULIT PISANG RAJA TERHADAP KARAKTERISTIK SENSORI ES KRIM
}

\author{
Study of Utilization of Flesh and Banana Peel Flour To \\ Sensory Characteristics of Ice Cream \\ Titis Fitri Asih, Siti Mujdalipah \\ Program Studi Pendidikan Teknologi Agroindustri, \\ Fakultas Pendidikan Teknologi dan Kejuruan, Universitas Pendidikan Indonesia \\ E-mail: titisfitriasih@gmail.com
}

\begin{abstract}
ABSTRAK
Es krim merupakan salah satu jenis pangan populer di dunia dan digemari oleh semua kalangan mulai dari anak-anak hingga orang dewasa. Saat ini, teknologi dan ilmu pengetahuan sangat berkembang, sehingga diperlukan inovasi untuk meningkatkan manfaat es krim bagi konsumen dengan cara pembuatan es krim prebiotik yang aman dan baik untuk sistem pencernaan. Salah satunya yaitu dengan memanfaatkan buah pisang beserta kulitnya. Pisang mengandung karbohidrat frukto-oligosakarida dan inulin yang mana merupakan sumber prebiotik. Prebiotik merupakan bahan pangan yang tidak dapat dicerna, memiliki efek menguntungkan terhadap inang dengan menstimulir pertumbuhan secara selektif terhadap bakteri di dalam usus. Kulit pisang raja berpotensi untuk menghasilkan senyawa pektin. Sifat penstabil pektin pada kulit pisang raja juga dapat dimanfaatkan sebagai bahan penstabil (stabilizer) dalam proses pembuatan es krim. Tujuan dari penelitian ini adalah mengetahui pengaruh perlakuan terhadap karakteristik sensori es krim. Penelitian ini disusun menggunakan rancangan acak lengkap (RAL) dengan dua faktor yaitu konsentrasi penambahan tepung buah pisang sebanyak 5\%, $10 \%$ dan konsentrasi penambahan tepung kulit pisang sebanyak $2 \%$ dan $4 \%$. Hasil penelitian menunjukkan bahwa perlakuan penambahan tepung buah pisang $10 \%$ dan tepung kulit pisang $4 \%$ menghasilkan es krim dengan karakteristik organoleptik es krim terbaik yaitu warna abu kecoklatan, aroma agak khas pisang, tekstur agak lembut, dan rasa agak khas pisang.
\end{abstract}

Kata kunci: tepung pisang, kulit pisang, es krim

\section{ABSTRACT}

Ice cream is one type of dish that is popular in the world and favored by all people ranging from children to adults. At present, technology and science are highly developed, so innovation is needed to increase the benefits of ice cream for consumers by making prebiotic ice cream which is good for the digestive system. One of them is by using flesh bananas and their peel. Bananas contain fructo-oligosaccharide and inulin carbohydrates which are prebiotic sources. Prebiotics are food ingredients that cannot be digested, have a beneficial effect on the host by stimulating selective growth of bacteria in the intestine. Plantain bark has the potential to produce pectin compounds. The properties of pectin stabilizers in plantain skin can also be used as stabilizers in the process of making ice cream. The purpose of this study was to determine the effect of treatment on sensory characteristics of ice cream. This study was arranged using a completely randomized design with two factors, namely the addition concentration of flesh banana flour by $5 \%$, $10 \%$ and the addition concentration of banana peel flour by $2 \%$ and $4 \%$. The results showed that the addition of banana flour $10 \%$ and banana peel flour $4 \%$ produced the best ice cream. The ice cream has brownish gray color, rather typical banana aroma, slightly soft texture, and rather typical banana flavor.

Key words: banana flesh, banana peel, ice cream 


\section{PENDAHULUAN}

Indonesia merupakan negara padat penduduk yang terus meningkat dari tahun ke tahun. Hal tersebut tentu berpengaruh terhadap tingginya tingkat konsumsi pada suatu produk pangan. Es krim merupakan salah satu jenis pangan populer di dunia dan digemari oleh semua kalangan mulai dari anak-anak hingga orang dewasa. Konsumsi es krim di Indonesia adalah yang terbesar di Asia Tenggara, yaitu mencapai 158 juta liter per tahun. Pada tahun 2018, diproyeksikan pertumbuhan konsumsi es krim di Indonesia mencapai 240 juta liter atau rata-rata tumbuh 8,75\% (neraca.co.id). Faktor utama dalam pertumbuhan konsumsi es krim adalah kondisi cuaca di Indonesia yang panas, pertumbuhan jumlah penduduk yang diikuti dengan peningkatan daya beli, dan tingginya persentase kelompok usia muda.

Es krim adalah produk pangan beku yang dibuat melalui kombinasi proses pembekuan dan agitasi pada campuran bahan-bahan yang terdiri dari susu dan produk susu, bahan pemanis, bahan penstabil, bahan pengemulsi, serta penambah cita rasa (Marshall dan Arbuckle, 1996). Saat ini, ilmu pengetahuan dan teknologi sangat berkembang, sehingga diperlukan inovasi untuk meningkatkan manfaat es krim bagi konsumen dengan cara pembuatan es krim prebiotik yang aman dan baik untuk sistem pencernaan. Salah satunya yaitu dengan memanfaatkan buah pisang beserta kulitnya.

Buah pisang merupakan salah satu buah-buahan yang memiliki potensi dan nilai ekonomi yang tinggi baik di dalam negeri maupun ekspor. Produksi buah pisang di Indonesia sangat melimpah dan menduduki tempat yang pertama diantara jenis buah-buahan lainnya. Pisang mengandung karbohidrat frukto-oligosakarida dan inulin yang mana merupakan sumber prebiotik. Prebiotik adalah salah satu jenis pangan fungsional yang masih dikembangkan. Prebiotik merupakan bahan pangan yang tidak dapat dicerna, memiliki efek menguntungkan terhadap inang dengan menstimulir pertumbuhan secara selektif terhadap bakteri di dalam usus (Laktobacili dan Bifidobakteria), sehingga meningkatkan kesehatan inang (Gibson, 2004; Roberfroid, 2007). Penelitian ini akan memanfaatkan buah pisang yang setengah matang karena kandungan prebiotiknya masih tinggi dibandingkan pisang yang terlalu matang sehingga akan diolah terlebih dahulu menjadi tepung.

Saat ini pemanfaatan kulit pisang di masyarakat masih terbatas sebagai pakan ternak. Menurut Munadjin (1998), kulit pisang merupakan bahan buangan (limbah buah pisang) yang cukup banyak jumlahnya yaitu kira-kira $1 / 3$ dari buah pisang yang belum dikupas. Padahal, kulit pisang mengandung nilai gizi yang cukup lengkap dan dapat diolah menjadi makanan yang bergizi tinggi. Kulit pisang raja berpotensi untuk menghasilkan senyawa pektin. Kandungan pektin dalam kulit pisang berkisar antara $0,9 \%$ dari berat kering. Pektin digunakan secara luas sebagai komponen fungsional pada makanan karena kemampuannya menstabilkan emulsi. Sifat penstabil pektin pada kulit pisang raja juga dapat dimanfaatkan sebagai bahan penstabil (stabilizer) dalam proses pembuatan es krim. Pada penelitian ini kulit pisang akan dimanfaatkan menjadi tepung untuk pengemulsi tambahan dalam pengolahan es krim dengan perlakuan yang ditambahkan yaitu konsentrasi sebesar $2 \%$ dan $4 \%$.

Penelitian ini bertujuan untuk membuat es krim dari tepung buah dan tepung kulit pisang raja serta mengetahui pengaruh konsentrasi penambahan tepung buah pisang dan tepung kulit pisang raja terhadap karakteristik sensori es krim.

\section{METODE}

Bahan yang digunakan dalam penelitian ini adalah buah pisang raja setengah matang yang didapat di Pasar Gerlong Kota Bandung, asam askorbat, susu sapi segar yang didapat di KPSBU Lembang, CMC, pengemulsi (kuning telur), air, gula, susu skim, whip cream, dan es batu. Peralatan yang digunakan dalam penelitian ini adalah mixer, lemari es, loyang, oven, grinder, timbangan, kompor gas, panci, baskom, sendok, cup, pisau, talenan, termometer, dan alat gelas lainnya. 
Pembuatan tepung buah dan kulit pisang raja diawali dengan mensortasi buah pisang. Kemudian, buah pisang dikupas dan memisahkan buah dengan kulitnya. Selanjutnya, pisang di blansing dengan cara dikukus atau disteam pada suhu $80^{\circ} \mathrm{C}$ selama $5-10$ menit. Proses ini dilakukan agar menghambat reaksi pencoklatan akibat oksidasi. Selanjutnya, buah pisang dikecilkan ukuran menggunakan alat slice agar pengecilan ukuran seragam, sedangkan pengecilkan ukuran pada kulit pisang dipotong kecil menggunakan pisau. Setelah itu, buah dan kulit pisang dikeringkan menggunakan oven pada suhu $50^{\circ} \mathrm{C}$ selama 24 jam. Selanjutnya, buah dan kulit pisang dihancurkan menggunakan grinder dan diayak menggunakan ayakan trailer 100 mesh untuk buah pisang dan 80 mesh untuk kulit pisang.

Susu sapi segar dipasteurisasi menggunakan metode LTLT (Low Temerature Long Time) dengan suhu $60^{\circ} \mathrm{C}$ selama 30 menit. Selanjutnya yaitu pencampuran bahan-bahan lainnya seperti gula $10 \%$, susu skim $10 \%$, whipped cream $10 \%$, kuning telur, CMC $1 \%$, tepung buah pisang raja A1 dan A2 (5\% dan 10\%) dan tepung kulit pisang raja B1 dan B2 (2\% dan $4 \%)$ menggunakan mixer hingga homogen dengan kecepatan sedang selama 15 menit. Setelah itu, adonan disimpan dalam lemari pendingin selama 24 jam hingga membeku. Adonan yang telah dibekukan, dilakukan kembali homogenisasi menggunakan mixer hingga mengembang dengan cara menempatkan baskom yang dikelilingi es batu. Selanjutnya campuran diukur kembali volume serta beratnya. Setelah itu, campuran dimasukkan ke dalam cup dan disimpan dalam lemari pendingin hingga membeku dan menjadi es krim.

Setelah es krim tepung buah dan tepung kulit pisang raja dihasilkan, selanjutnya dilakukan analisis organoleptik hedonik dan mutu hedonik (Modifikasi Soekarto, 1985) meliputi parameter warna, aroma, tekstur, dan rasa dengan menggunakan 20 panelis agak terlatih.

Metode penelitian yang digunakan pada penelitian ini adalah metode eksperimental menggunakan rancangan percobaan berupa Rancangan Acak Lengkap (RAL) dua faktor yaitu:

Faktor 1 : konsentrasi tepung buah pisang yang disimbolkan dengan huruf $(A)$

$\mathrm{A} 1=$ konsentrasi tepung buah pisang $5 \%$

A2 $=$ konsentrasi tepung buah pisang $10 \%$

Faktor 2 : konsentrasi tepung kulit pisang yang disimbolkan dengan huruf (B)

B1 $=$ konsentrasi tepung kulit pisang $2 \%$

B2 $=$ konsentrasi tepung kulit pisang $4 \%$

Percobaan tersebut dilakukan sebanyak 2 kali ulangan. Rancangan percobaan tersaji pada tabel 1.

Tabel 1. Rancangan Percobaan

\begin{tabular}{cccc}
\hline \multirow{2}{*}{ Tepung Buah Pisang } & \multirow{2}{*}{ Ulangan $(r)$} & \multicolumn{2}{c}{ Tepung Kulit Pisang } \\
\cline { 2 - 4 } & & B1 & $B 2$ \\
\hline \multirow{2}{*}{ A1 } & 1 & $(A 1 B 1)_{1}$ & $(A 1 B 2)_{1}$ \\
\cline { 2 - 4 } & 2 & $(A 1 B 1)_{2}$ & $(A 1 B 2)_{2}$ \\
\hline \multirow{2}{*}{ A2 } & 1 & $(A 2 B 1)_{1}$ & $(A 2 B 2)_{1}$ \\
\cline { 2 - 4 } & 2 & $(A 2 B 1)_{2}$ & $(A 2 B 2)_{2}$ \\
\hline
\end{tabular}

Analisis data hasil penelitian ini dilakukan dengan Analisis of Variabel (ANOVA) menggunakan aplikasi Microsoft Excel 2010, kemudian apabila hasil ANOVA berbeda nyata, analisis dilanjutkan dengan Uji Duncan menggunakan Microsoft Excel 2010.

\section{HASIL DAN PEMBAHASAN \\ Warna Es Krim}

Warna merupakan salah satu atribut kualitas yang penting. Warna menentukan tingkat penerimaan konsumen akan bahan pangan (Fennema, 1985). Warna merupakan komponen yang sangat penting untuk menentukan kualitas atau derajat penerimaan suatu bahan pangan meskipun aroma dan teksturnya sangat baik, tetapi memiliki warna yang kurang menarik atau memberikan 
kesan menyimpang dari warna yang seharusnya maka produk pangan tersebut akan terlihat tidak layak untuk dikonsumsi. Hasil uji mutu hedonik terhadap warna tersaji pada table 2.

Tabel 2. Hasil Uji Mutu Hedonik Parameter Warna

\begin{tabular}{ccc}
\hline Perlakuan & Warna & Kategori \\
\hline A1B1 & 1,77 & Agak abu kecoklatan \\
\hline A1B2 & 2,70 & Abu kecoklatan \\
\hline A2B1 & 1,80 & Agak abu kecoklatan \\
\hline A2B2 & 2,77 & Abu kecoklatan
\end{tabular}

Berdasarkan tabel 2, es krim dengan penambahan konsentrasi tepung kulit pisang $2 \%$ yang disimbolkan B1 menghasilkan nilai mutu dengan kategori agak abu kecoklatan dilihat pada perlakuan A1B1 dan A2B1. Sedangkan es krim dengan penambahan konsentrasi tepung kulit pisang $4 \%$ yang disimbolkan B2 menghasilkan nilai mutu dengan kategori abu kecoklatan dilihat pada perlakuan A1B2 dan A2B2. Dengan demikian, maka semakin tinggi konsentrasi tepung kulit pisang yang ditambahkan, warna es krim yang dihasilkan semakin cokelat.

Hasil analisis sidik ragam atau ANOVA menunjukkan bahwa perlakuan penambahan tepung kulit pisang berpengaruh nyata terhadap wana es krim dibuktikan dengan $F$ hitung faktor $B$ (tepung kulit pisang) $>\mathrm{F}$ tabel pada taraf $5 \%$. Hal tersebut diduga karena tepung kulit pisang yang dihasilkan berwarna cokelat sehingga mengakibatkan es krim prebiotik yang dihasilkanpun berwarna kecoklatan. Diduga, saat pembuatan tepung kulit pisang, terjadi proses proses pencoklatan enzimatis akibat adanya reaksi Maillard sehingga mengakibatkan tepung kulit pisang yang dihasilkan berwarna cokelat. Tepung kulit pisang yang berwarna cokelat diduga berasal dari komponen polifenol dan tannin yang terkandung didalamnya bereaksi secara enzimatis dengan komponen karbohidrat. Sejalan dengan pendapat Winarno (2004), yang menyatakan bahwa terjadinya reaksi pencoklatan enzimatis karena adanya reaksi Maillard yang merupakan reaksi antara karbohidrat, khususnya gula pereduksi dengan gugus amina primer. Selain itu, menurut Dita et al., (2014) menyatakan bahwa kulit buah pisang mengandung senyawa fenolik, flavonoid dan tannin. Hasil analisis sidik ragam yang berpengaruh nyata, maka dilakukan uji lanjut Duncan yang hasilnya tersaji pada tabel 3 .

Tabel 3. Hasil Uji Duncan Mutu Hedonik Parameter Warna

\begin{tabular}{cc}
\hline Perlakuan & Rataan \\
\hline A1B1 & $1,48^{\mathrm{a}}$ \\
\hline A1B2 & $1,78^{\mathrm{abc}}$ \\
\hline A2B1 & $1,50^{\mathrm{ab}}$ \\
\hline A2B2 & $1,79^{\mathrm{bc}}$ \\
\hline
\end{tabular}

Berdasarkan hasil uji Duncan mutu hedonik parameter warna diatas, dapat diketahui bahwa perlakuan dengan penambahan tepung buah 10\% dan tepung kulit 4\% (A2B2) tidak berbeda dengan perlakuan penambahan tepung kulit yang sama yaitu 4\% (A1B2). Hal tersebut dibuktikan dengan notasi huruf $C$ yang dimiliki pada kedua perlakuan tersebut. Sedangkan perlakuan A2B2 sangat berbeda dengan perlakuan A1B1 dimana penambahan tepung kulit dan tepung buah antar kedua perlakuan berbeda. Namun, perlakuan A2B2 sedikit berbeda dengan perlakuan A2B1 dikarenakan pada kedua perlakuan tersebut memiliki kesamaan dalam konsentrasi penambahan tepung buah $10 \%$ yang disimbolkan $\mathrm{A} 2$.

Penilaian kesukaan panelis terhadap warna es krim prebiotik tepung buah pisang dan tepung kulit pisang raja dapat dilihat pada uji hedonik atau uji kesukaan, tersaji pada tabel 4 . 
Tabel 4. Hasil Uji Hedonik Parameter Warna

\begin{tabular}{ccc}
\hline Perlakuan & Warna & Kategori \\
\hline A1B1 & 3,07 & Suka \\
\hline A1B2 & 2,57 & Agak suka \\
\hline A2B1 & 3,03 & Suka \\
\hline A2B2 & 2,57 & Agak suka \\
\hline
\end{tabular}

Berdasarkan hasil uji hedonik parameter warna diatas, dapat diketahui bahwa perlakuan A1B1 dan A2B1 lebih disukai panelis. Pada kedua perlakuan tersebut terdapat kesamaan dalam penambahan tepung kulit pisang $2 \%$. Dilihat dari hasil uji mutu hedonik yang dapat dilihat pada tabel 2, perlakuan A1B1 dan A2B1 memiliki warna es krim agak abu kecoklatan. Sedangkan perlakuan A1B2 dan A2B2 tidak begitu disukai panelis karena memiliki warna yang lebih tajam yang mana jika dilihat berdasarkan mutu hedonik warna pada kedua perlakuan tersebut yaitu abu kecoklatan.

Hasil analisis sidik ragam menunjukkan bahwa perlakuan penambahan tepung kulit pisang berpengaruh nyata terhadap wana es krim dibuktikan dengan $F$ hitung faktor $B$ (tepung kulit pisang) > $\mathrm{F}$ tabel pada taraf $5 \%$ maka dilakukan uji lanjut duncan. Hasil uji lanjut Duncan hedonik pada parameter warna disajikan pada tabel 5 .

Tabel 5. Hasil Uji Lanjut Duncan Hedonik Parameter Warna

\begin{tabular}{cc}
\hline Perlakuan & Rataan \\
\hline A1B1 & $1,88^{\mathrm{c}}$ \\
\hline A1B2 & $1,74^{\mathrm{a}}$ \\
\hline A2B1 & $1,87^{\mathrm{abc}}$ \\
\hline A2B2 & $1,74^{\mathrm{ab}}$ \\
\hline
\end{tabular}

Berdasarkan hasil uji duncan diatas, terlihat bahwa perlakuan A1B1 tidak berbeda dengan perlakuan A2B1. Namun, A1B1 berbeda dengan perlakuan A1B2 dan A2B2. Hal tersebut dapat berarti bahwa perlakuan dengan penambahan konsentrasi tepung pisang yang sama tidak menghasilkan warna yang berbeda, namun hasilnya akan berbeda jika dibandingkan dengan penambahan konsentrasi tepung pisang yang berbeda pula. Semakin tinggi konsentrasi penambahan tepung kulit pisang, maka warna es krim yang dihasilkan semakin semakin coklat.

\section{Aroma}

Aroma merupakan atribut penting dalam menilai suatu produk pangan. Uji terhadap aroma dianggap penting karena dengan cepat dapat memberikan penilaian minat konsumen terhadap hasil produksinya (Soekarto,1995). Hasil organoleptik mutu hedonik terhadap aroma es krim dapat dilihat pada tabel 6 .

Tabel 6. Hasil Uji Mutu Hedonik Parameter Aroma

\begin{tabular}{ccc}
\hline Perlakuan & Aroma & Kriteria \\
\hline A1B1 & 2,07 & Agak khas pisang \\
\hline A1B2 & 1,93 & Agak khas pisang \\
\hline A2B1 & 2,03 & Agak khas pisang \\
\hline A2B2 & 2,10 & Agak khas pisang \\
\hline
\end{tabular}

Berdasarkan Berdasarkan tabel 6, rata-rata penilian panelis terhadap aroma es krim sama yaitu agak khas pisang. Hal tersebut disebabkan karena buah pisang maupun kulitnya dijadikan produk tepung. Menurut Ismayani (2007), menyebutkan bahwa tepung pisang mempunyai kelemahan yaitu aroma pisangnya kurang kuat. Diduga, saat proses penepungan, senyawa 
polifenol yang terdapat pada buah pisang maupun kulitnya hilang akibat proses pengeringan menggunakan oven. Selain itu, diduga karena faktor dari buah pisang yang digunakan belum terlalu matang sehingga aroma nya belum kuat karena senyawa volatil pembentuk aroma dan flavour belum maksimal. Komponen pembentuk aroma dan flavor adalah hidrokarbon terpen, komponen karbonil, alkohol, dan ester (Anonim, 2009). Senyawa-senyawa volatil ini akan mencapai jumlah maksimal ketika buah matang secara sempurna dan menghasilkan aroma yang kuat.

Penilaian kesukaan panelis terhadap aroma es krim prebiotik tepung buah pisang dan tepung kulit pisang raja dapat dilihat pada uji hedonik atau uji kesukaan tersaji pada tabel 7.

Tabel 7. Hasil Uji Hedonik Paramter Aroma

\begin{tabular}{ccc}
\hline Perlakuan & Aroma & Kategori \\
\hline A1B1 & 2,63 & Agak suka \\
\hline A1B2 & 2,60 & Agak suka \\
\hline A2B1 & 2,67 & Agak suka \\
\hline A2B2 & 2,60 & Agak suka
\end{tabular}

Berdasarkan tabel diatas, nilai rata-rata terhadap aroma es krim yang diberikan oleh panelis yaitu agak suka pada keempat perlakuan. Diduga, pada keempat perlakuan tersebut, es krim yang dihasilkan tidak memiliki aroma pisang yang kuat sehingga kurang disukai oleh panelis.

Hasil analisis sidik ragam menyatakan bahwa perlakuan penambahan tepung buah pisang, tepung kulit pisang, dan interaksi antara tepung buah dan tepung kulit pisang tidak berpengaruh nyata terhadap aroma es krim yang dihasilkan karena $F$ hitung $<F$ tabel sehingga tidak dilakukan uji lanjut Duncan. Hal tersebut dapat terjadi karena dari kedua faktor yaitu tepung buah pisang dan tepung kulit pisang yang digunakan tidak memiliki aroma yang kuat.

\section{Tekstur}

Salah satu parameter mutu yang sangat berperan dalam menampilkan karateristik es krim adalah tekstur. Dari tekstur bisa dirasakan sensasi kenyal, keras, lembut, empuk, atau alot dan lengket, halus atau kasar berpasir, dan lainnya. Tekstur es krim yang ideal adalah halus dan partikel padatan terlalu kecil untuk dapat dirasakan di mulut. Menurut Szczesniak (1998), menyatakan bahwa tekstur berpasir (coarseness) dapat menunjukkan bahwa kristal besar dengan ukuran yang tidak seragam atau sel-sel udara terlalu besar. Hasil uji mutu hedonik terhadap tekstur es krim disajikan pada tabel 8.

Tabel 8. Hasil Uji Mutu Hedonik Paramaeter Tekstur

\begin{tabular}{ccc}
\hline Perlakuan & Tekstur & Kriteria \\
\hline A1B1 & 3,10 & Lembut \\
\hline A1B2 & 2,80 & Lembut \\
\hline A2B1 & 2,67 & Lembut \\
\hline A2B2 & 2,73 & Lembut \\
\hline
\end{tabular}

Hasil uji mutu hedonik terhadap tekstur es krim menunjukkan bahwa hasil penilaian panelis pada semua perlakuan sama yaitu lembut. Tekstur lembut yang dihasilkan disebabkan karena partikel padatan yang ada dalam es krim kecil sehingga menyebaban tekstur yang dihasilkan masih lembut. Tekstur lembut yang dihasilkan juga disebabkan karena sel-sel udara yang dihasilkan saat pengembangan/pengocokan dalam es krim tidak terlalu besar. Sel-sel udara yang ada, berperan untuk memberikan tekstur lembut pada eskrim tersebut. Tanpa adanya udara, emulsi beku tersebut akan menjadi terlalu dingin dan terlalu berlemak. Sebaliknya, jika kandungan udara dalam es krim terlalu banyak akan terasa lebih cair dan lebih hangat sehingga tidak enak dimakan.

Penilaian kesukaan panelis terhadap tekstur es krim prebiotik tepung buah pisang dan 
tepung kulit pisang raja dapat dilihat pada uji hedonik atau uji kedukaan tersaji pada tabel 9.

Tabel 9. Hasil Uji Hedonik Tekstur

\begin{tabular}{ccc}
\hline Perlakuan & Tekstur & Kategori \\
\hline A1B1 & 2,60 & Agak suka \\
\hline A1B2 & 2,57 & Agak suka \\
\hline A2B1 & 2,60 & Agak suka \\
\hline A2B2 & 2,53 & Agak suka \\
\hline
\end{tabular}

Berdasarkan tabel diatas, nilai rata-rata terhadap tekstur es krim yang diberikan oleh panelis yaitu agak suka pada keempat perlakuan. Diduga, pada keempat perlakuan tersebut, es krim yang dihasilkan tidak memiliki tekstur yang disukai oleh panelis. Tekstur es krim yang dihasilkan lembut, namun, jika dirasakan dalam mulut, masih terdapat tekstur seperti tepung. Hal tersebut dapat mempengaruhi tingkat kesukaan panelis.

Hasil analisis sidik ragam menyatakan bahwa perlakuan penambahan tepung buah pisang, tepung kulit pisang, dan interaksi antara tepung buah dan tepung kulit pisang tidak berpengaruh nyata terhadap tekstur es krim yang dihasilkan karena $F$ hitung $<F$ tabel sehingga tidak dilakukan uji lanjut Duncan.

\section{Rasa}

Rasa merupakan hal yang sangat diperhatikan dalam pembuatan suatu produk. Rasa merupakan rangsangan yang ditimbulkan oleh bahan yang dimakan, terutama dirasakan oleh indera pengecap. Rasa pada suatu makanan dipengaruhi oleh penggunaan bahan dasar pembuatan produk itu sendiri. Suatu produk dapat diterima oleh konsumen apabila memiliki rasa yang sesuai dengan yang diinginkan (Kartika, dkk, 1988). Hasil uji mutu hedonik terhadap rasa es krim tersaji pada tabel 10.

Tabel 10. Hasil Uji Mutu Hedonik Parameter Rasa

\begin{tabular}{ccc}
\hline Perlakuan & Rasa & Kriteria \\
\hline A1B1 & 2,50 & Agak khas pisang \\
\hline A1B2 & 2,30 & Agak khas pisang \\
\hline A2B1 & 2,27 & Agak khas pisang \\
\hline A2B2 & 2,53 & Agak khas pisang \\
\hline
\end{tabular}

Hasil uji mutu hedonik terhadap rasa es krim menunjukkan bahwa hasil penilaian panelis pada semua perlakuan sama yaitu agak khas pisang. Tepung bauh pisang dan tepung kulit pisang yang digunakan tidak memiliki rassa yang kuat sehingga tidak terlihat perbedaan yang signifikan pada setiap perlakuannya.

Rasa yang kurang kuat pada tepung buah pisang dan tepung kuit pisang, disebabkan oleh beberapa faktor seperti pisang raja yang digunakan pisang setengah matang sehingga rasa manis dari pisang yang dihasilkan kurang terasa. Menurut Yuniarti (1992), tingkat kematangan buah saat dipanen akan mempengaruhi mutu rasa buah ketika masak. Buah yang belum matang memiliki rasa yang kurang manis, masam, ataupun hambar. Aroma buah yang belum matang juga tidak akan berkembang. Oleh karena itu buah yang belum matang jika diolah menjadi produkpun tidak memiliki aroma menyengat seperti pada buah yang telah matang matang. Selain itu, dalam proses pengolahannya juga buah pisang dijadikan tepung dahulu yang mana mengalami proses pengeringan yang cukup lama sehingga rasa pisang tidak berasa. Winarno (2004) pun menambahkan bahwa rasa dipengaruhi oleh beberapa faktor, seperti senyawa kimia, suhu, komposisi komponen-komponen bahan penyususun es krim dan interaksi komponen rasa lain.

Penilaian kesukaan panelis terhadap rasa es krim prebiotik tepung buah pisang dan tepung kulit pisang raja dapat dilihat pada uji hedonik atau uji kedukaan tersaji pada tabel 11. 
Tabel 11. Hasil Uji Hedonik Parameter Rasa

\begin{tabular}{ccc}
\hline Perlakuan & Rasa & Kategori \\
\hline A1B1 & 2,70 & Agak suka \\
\hline A1B2 & 2,67 & Agak suka \\
\hline A2B1 & 2,63 & Agak suka \\
\hline A2B2 & 2,50 & Agak suka
\end{tabular}

Berdasarkan tabel 11, nilai rata-rata terhadap rasa es krim yang diberikan oleh panelis yaitu agak suka untuk keempat perlakuan. Hal tersebut diduga disebabkan karena rasa pisang yang terdapat dalam es krim tidak terlalu kuat sehingga kurang disukai oleh panelis.

Hasil analisis sidik ragam menyatakan bahwa perlakuan penambahan tepung buah pisang, tepung kulit pisang, dan interaksi antara tepung buah dan tepung kulit pisang tidak berpengaruh nyata terhadap rasa es krim yang dihasilkan karena $F$ hitung $<F$ tabel sehingga tidak dilakukan uji lanjut Duncan.

\section{KESIMPULAN}

1. Penambahan tepung kulit pisang berpengaruh nyata terhadap warna es krim. Namun, perlakuan perlakuan penambahan tepung buah pisang, tepung kulit pisang, dan interaksi antara tepung buah dan tepung kulit tidak berpengaruh nyata terhadap aroma, tekstur, dan rasa es krim yang dihasilkan.

2. Perlakuan terbaik didapat pada perlakuan $A 2 B 2$ dengan penambahan tepung buah pisang sebanyak $10 \%$ dan tepung kulit pisang sebanyak 4\% dengan karakteristik organoleptik es krim yaitu warna abu kecoklatan, aroma agak khas pisang, tekstur agak lembut, dan rasa agak khas pisang.

\section{DAFTAR PUSTAKA}

Arbuckle, W.S. (1986). Ice Cream 4th Ed. The Avi Publishing Company, Inc. Wesport Connecticut, London.

Dita AF., Suryanto, E dan Wewengkang, S. Defny. (2014). Aktivitas Antioksidan pada Ekstrak Kulit Buah Pisang Goroho (Musa acuminate L.). Junal Ilmiah Farmasi. Pharmacon. 3 : 2302 2493.

Gibson G.R. (2004). Dietary modulation of the human colonic microbiota: updating the concept of prebiotics. Journal Nutrition. Res. Rev. (17): 259 - 275

Ismayani, Yeni. (2007). Tips Anti Gagal Bikin Kue. Jakarta. PT. Kawan Pustaka.

Kartika, dkk. (1988). Pedoman Uji Inderawi Bahan Pangan. Yogyakarta: UGM.

Marshall, R. T. and S. Arbuckle. (1996). Ice Cream. 5th ed. Champhan and Hall Publishing, New York.

Munadjim. (1998). Teknologi Pengolahan Pisang. Gramedia. Jakarta.

Roberfroid, M. (2005). Inulin-type Fructans : Functional Food Ingredients. CRC Press. Florida. . (2007). Prebiotics: The concept revisited effect of probiotics and prebiotics. Journal Nutrition (137): 830S - 837S.

Soekarto, S. T. (1985). Penilaian Organoleptik untuk Industry Pangan Hasil Pertanian. Bharata Daya Aksara. Jakarta.

Soekarto, S.T. (1995). Penilaian Organoleptik untuk Industri Pangan dan Hasil Pertanian. Bharata, Yogyakarta.

Szczesniak A.S. (1998). Effect of Storage on Texture. In Food Storage Stability. Taub IA, Singh RP. CRC Press, USA.

Winarno, F.G. (2004). Kimia Pangan dan Gizi. Jakarta: Gramedia Pustaka Utama.

Yuniarti. (1992). Penanganan dan Pengolahan Buah Mangga. Yogyakarta : Kanisius. 